\title{
Quantification of lactic acid bacteria and bifidobacteria in goat milk based yoghurts with added water-soluble soy extract
}

\author{
Danielle Cristina Guimarães da Silva*, Danilo Florisvaldo Brugnera and \\ Luiz Ronaldo de Abreu
}

\author{
UFLA, Lavras, MG, Brasil.
}

Accepted 2 August, 2013

\begin{abstract}
This work was carried out with the objective of evaluating the microbiological aspects, during 29 days of storage, through the quantification of viable cells and probiotic bacteria enumeration, of strawberry flavored yoghurts produced with goat milk with water-soluble soy extract and Bifidobacterium animalis ssp. lactis probiotic culture during processing. Determination of the viable cell count during yoghurt storage showed that the number of lactic bacteria found was below the expected only in the treatment in which there was water-soluble soy extract addition, not presenting microbiological viability. The other yoghurt treatments were viable during storage. The enumeration of Bifidobacterium animalis ssp. lactis showed that the yoghurt treatments presented microbiological viability during storage. We concluded that the addition of water-soluble soy extract interfered negatively with the production of goat milk based yoghurts.
\end{abstract}

Key words: Yoghurt, water-soluble soy extract, lactic acid bacteria, Bifidobacterium.

\section{INTRODUCTION}

Yoghurt is a very popular fermented milk product produced by lactic acid fermentation of milk by addition of a starter culture containing Streptococcus thermophilus and Lactobacilus delbrueckii ssp. bulgaricus. It is a very versatile product that suits all palates and meal occasions (Isleten and Karagul-Yuceer, 2006). Besides the traditional culture, strains of other probiotic organisms, such as lactobacilli and bifidobacteria, have been used in fermented products as potential health promoters. The supplementation of fermented products with probiotic bacteria becomes beneficial by providing better use of the lactose, anticarcinogenic activity and intestinal infec-tion control. Probiotics are referred to as "live microorganisms, which when administered in adequate amounts confer a health benefit on the host" (FAO/WHO, 2001; Allgeyer et al., 2010).
Strains of $L$. acidophilus and of Bifidobacterium lactis predominate in commercial probiotic products (Tabasco et al., 2007). The presence of multiple species in these products makes the differential enumeration between probiotic bacteria and starter cultures necessary. Numerous means have been proposed for selectivity and differential enumeration of lactobacilus and bifidobacteria in bacterial population mixtures.

In relation to other types of milk, goat milk presents advantages such as smaller size fat globules, low allergenic properties (Martín-Diana et al., 2003), a balance of essential amino acids, high levels of calcium, selenium, phosphate and rich in vitamins $A$ and $B$. However, goat milk is deficient in folic acid and vitamin D. Furthermore, a certain therapeutic value in human nutrition has been attributed to goat milk (Alférez et al. 
2006). The use of goat milk as an excellent food source is undeniable. It has beneficial effects on health maintenance, physiological functions, in the nutrition of children and elderly people, and according to some authors, can be consumed without negative effects of suffering from cow milk allergy. This highlights the market potential of goat milk (Ribeiro and Ribeiro, 2010).

The elaboration of the yoghurts based on goat milk, can present significant alterations in its rheological properties, such as low consistency and a tendency towards whey separation (syneresis). Therefore, to obtain satisfactory results with fermented goat milk products, the addition of stabilizers is recommended. The enrichment of the dry matter content and/or the protein content are standard measures used to avoid syneresis and to improve the texture of the yoghurt. As such, the soy proteins, specifically, the water-soluble soy extract (WSSE), deserves prominence to improve the nutritional value of the product and to affect the gel structure formation of the yoghurt (Silva et al., 2012).

The nutritional deficiency of goat milk can be improved by the lactic fermentation process. According to Hugenholtz (2008), many lactic bacteria seem to produce some vitamins, where the fermented product is enriched as a result of the bacterial production. The fermented milk products are reported as containing high amounts of folates, as a result of the additional folate production via bacteria. Therefore, from the choice of viable starter cultures, the natural fortification of a milk product can be undertaken. Silanikove et al. (2010) reported that the quality and safety of goat milk are optimized to ensure consumer confidence owing to the growing interest in existing and new goat dairy products worldwide.

Based on the above, this research had the objective of evaluating the growth of total lactic acid bacteria and $B$. animalis ssp. lactis in goat milk based yoghurts with added water-soluble soy extract and probiotic culture during 29 days of refrigerated storage.

\section{MATERIALS AND METHODS}

\section{Characterization of the raw material}

The milk used in the experiment was through the milking of Saanen breed females. After milking, the milk was cooled immediately to $5^{\circ} \mathrm{C}$, transferred to previously sanitized polypropylene milk cans and transported to the dairy plant where the processes were conducted.

The physiochemical analyses were carried out with milk samples in triplicate, to proof its quality. It consisted of the determination of the $\mathrm{pH}$ by direct potentiometry in a digital pHmeter (Instituto Adolfo Lutz, 1985), titratable acidity, density, fat and total soluble solids percentage (Brazil, 2006).

\section{Preparation of the yoghurt}

The methodology used in this study for development of the yoghurt was based on that described by Tamine and Robinson (1991) as shown in Figure 1. The yoghurts were prepared and identified with letters according to their processing specifics (addition of WSSE adjusted to the protein level of the milk at a concentration of $20 \%$, resulting in the supplementation of $14.8 \mathrm{~g} / \mathrm{L}$ of water-soluble soy extract and $B$. animalis ssp. lactis probiotic culture (2\%), as expressed below:

1. Yoghurt A: without the WSSE addition, without addition of probiotic culture.

2. Yoghurt B: addition of WSSE (20\%), without the probiotic addition.

3. Yoghurt C: without addition of WSSE with added probiotic culture.

4. Yoghurt D: with WSSE (20\%) addition with added probiotic culture.

After analysis of the milk quality, WSSE was added in B and D treatments. Later, all the treatments were pasteurized at $80^{\circ} \mathrm{C}$ for $30 \mathrm{~min}$ and then cooled to $43^{\circ} \mathrm{C}$. The different combinations of bacterial cultures: $S$. thermophilus, L. delbrueckii ssp. bulgaricus and $B$. animalis ssp. lactis, were inoculated. The final fermentation point was determined when the yoghurts reached $\mathrm{pH} 4.6$ and were then removed from the oven and cooled to $15^{\circ} \mathrm{C}$ for the addition of the strawberry pulp and stored at $4^{\circ} \mathrm{C}$. The microbiological analyses of the products were conducted on the 1st, 8th, 15th, 22nd and 29th day, post-production.

\section{Viable lactic bacteria count during storage at $4^{\circ} \mathrm{C}$}

The lactic bacteria count was conducted by the pour plate method, with an overlay, adding $1 \mathrm{~mL}$ of diluted inoculum and adding a small amount of MRS agar in the Petri dishes. After solidification of the medium, an overlay was added, seeking the creation of a $15 \% \mathrm{CO}_{2}$ atmosphere, followed by incubation at $30^{\circ} \mathrm{C}$ for 5 days. After the required incubation time, the count was conducted in Petri dishes that presented between 25 and 250 colonies (Tebaldi et al., 2007).

\section{Probiotic count during storage at $4^{\circ} \mathrm{C}$}

For the enumeration of $B$. animalis ssp. lactis the MRS medium was used supplemented with $1 \%$ raffinose, $0.05 \%$ lithium chloride and $0.05 \%$ cysteine, sterilized by filtration in a $0.45 \mathrm{~mm}$ membrane. There was no use of antibiotics and the inoculation technique used was the pour plate, with overlay. After the inoculation, the Petri dishes were incubated inverted in jars containing anaerobiose generator (Anaerobac) at $45^{\circ} \mathrm{C}$ for $72 \mathrm{~h}$ (Tabasco et al., 2007).

\section{Statistical analysis}

The experiment was conducted in a completely randomized design (CRD), in a $2 \times 2 \times 5$ factorial ( 2 soy extract concentrations, 2 treatments with probiotic culture addition at 5 storage times). Three repetitions were carried out for each treatment. The effects of the different treatments were appraised by variance analysis (ANOVA), followed by the Scott-Knott Test, to $5 \%$ of significance, to express the differences in significant cases. The evaluation of the storage time of the yoghurts was analyzed through linear regression, after transformation of the data into logarithms (log). The variance analyses, test of averages and linear regression were carried out in the R software (R Development Core Team, 2009).

\section{RESULTS AND DISCUSSION}

\section{Characterization of raw material}

The results of the physiochemical analysis of the goat 
Glob. J. Food Sci. Technol. 093.

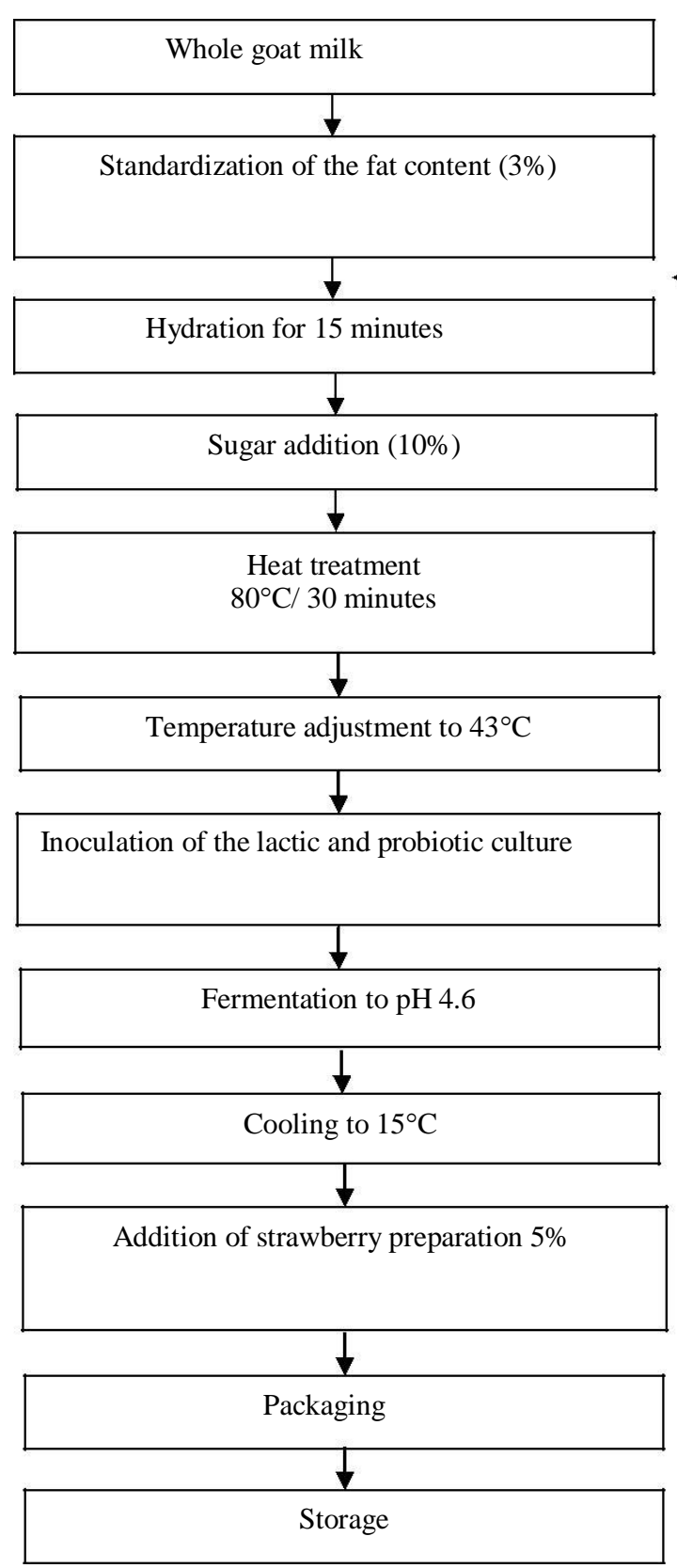

Figure 1. Flowchart of yoghurt preparation.

milk used in the yoghurt treatments are 6.68 from $\mathrm{pH}$, $0.17 \mathrm{~g}$ lactic acid $/ 100 \mathrm{~mL}$ of product from titratable acidity, $1.02 \mathrm{~g} \mathrm{~L}^{-1}$ from density, $3.1 \%$ from fat and $11.5 \%$ from total soluble solids. These results were similar to those found by Lora et al. (2006). The average value found for the goat milk acidity was $0.17 \mathrm{~g}$ lactic acid/100 $\mathrm{mL}$ of product. Such an average is within the standards required by the legislation (Brazil, 2000a).

The average fat value obtained in the raw milk by the Gerber method was above the minimum (3\%) required by the legislation for whole milk, density of the goat milk was within the norms of the current legislation (Brazil, 2000a).
Adition of WSSE (20\%) 
Table 1. Average count of the number of viable lactic acid bacteria from goat milk yoghurt samples with added WSSE and probiotics during storage time (CFU/ml).

\begin{tabular}{lccccc}
\hline \multirow{2}{*}{ Yoghurt } & \multicolumn{5}{c}{ (CFU/ml) } \\
\cline { 2 - 6 } & Day 1 & Day 8 & Day 15 & Day 22 & Day 29 \\
\hline A & $2.6 \times 10^{\prime} \mathrm{a}$ & $2.3 \times 10^{\prime} \mathrm{a}$ & $1.8 \times 10^{\prime} \mathrm{a}$ & $2.5 \times 10^{\prime} \mathrm{a}$ & $1.8 \times 10^{\prime} \mathrm{a}$ \\
$\mathrm{B}$ & $3.2 \times 10^{\circ} \mathrm{b}$ & $2.2 \times 10^{\circ} \mathrm{b}$ & $5.0 \times 10^{\circ} \mathrm{b}$ & $4.1 \times 10^{\circ} \mathrm{b}$ & $3.0 \times 10^{\circ} \mathrm{b}$ \\
$\mathrm{C}$ & $9.0 \times 10^{\circ} \mathrm{C}$ & $4.8 \times 10^{\circ} \mathrm{C}$ & $1.15 \times 10^{\prime} \mathrm{a}$ & $3.3 \times 10^{\prime} \mathrm{a}$ & $3.1 \times 10^{\prime} \mathrm{a}$ \\
$\mathrm{D}$ & $7.3 \times 10^{\circ} \mathrm{C}$ & $5.0 \times 10^{\circ} \mathrm{C}$ & $4.1 \times 10^{\circ} \mathrm{b}$ & $8.3 \times 10^{\circ} \mathrm{C}$ & $2.5 \times 10^{\circ} \mathrm{b}$ \\
\hline
\end{tabular}

Means followed by the same letter do not differ statistically among themselves, by ScottKnott Test Average, to $5 \%$ probability. Treatment: A (without addition of WSSE and without addition of probiotic culture), B (with addition of WSSE and without addition of probiotic culture), C (without addition of WSSE and with addition of probiotic culture), D (with addition of WSSE and with added probiotic culture).

existing Brazilian legislation which, according to the Identity and Quality Standards (PIQ) of Fermented Milk, Resolution No. 5, November 13, 2000 (Brazil, 2000b), the total viable lactic bacteria count should be at least $10^{7}$ $\mathrm{CFU} / \mathrm{mL}$ in the final product, during the entire validity period.

According to Silva (2007), studies have shown that the yoghurt bacteria ( $S$. thermophilus and $L$. delbrueckii ssp. bulgaricus) survive well in the product during the shelf life. L. bulgaricus is the bacterium mainly responsible for the post-acidification of the yoghurts, a factor that can alter the microbial count; on the other hand, this microorganism contributed considerably to the production of aromatic compounds, especially acetaldehyde, characteristic of the yoghurt.

In yoghurt $\mathrm{B}$, in which there was the WSSE addition, the viable lactic cell count remained between $2 \times 10^{6}$ to $3.0 \times 10^{6} \mathrm{CFU} / \mathrm{mL}$. From these results we observed that the product did not meet the values established by the legislation (Brazil, 2000b), which establishes that the total viable lactic bacteria count should be at least $10^{7}$ $\mathrm{CFU} / \mathrm{mL}$ in the final product, during the entire validity period. The excess lipids originating from the watersoluble soy extract can inhibit fermentation and microbial growth. This inhibition can occur due to the toxic effect of the unsaturated fatty acids on the bacterial cells. This toxic effect is associated with a change of the lipid composition and the physiochemical properties of the bacterial cell membranes (Kozloski, 2002).

The goat milk based yoghurt treatment codified by the letter C, with added B. animalis ssp. lactis probiotic culture, presented a sufficient count, being considered microbiologically viable according to the values established by the current law. Such law establishes that the total viable lactic bacteria count should be at least $10^{6}$ $\mathrm{CFU} / \mathrm{mL}$ in the final product, during the entire validity period, when there is bifidobacteria inoculation in fermented milk. During the entire yoghurt storage period, the viable lactic cell count remained between $9.0 \times 10^{6}$ and $3.1 \times 10^{7}$. In spite of the presence of multiple microbial species in a same food product leading to low microorganism counts, this was not observed in this study. According to Tamine and Robinson (1991), the $\mathrm{pH}$ value is involved with the metabolic activity of the bacteria, and may favor a particular group to the detriment of another.

The results of the determination of the viable lactic bacteria count during 29 days of storage show that the goat milk based yoghurt with added water-soluble soy extract and probiotic culture presented a count between $7.3 \times 10^{6}$ and $2.5 \times 10^{6}$. Therefore, this product presented microbiological viability during the storage time studied, an appropriate count according to current law being observed, which establishes that the total count of viable lactic bacteria should be at least $10^{6} \mathrm{CFU} / \mathrm{mL}$ in the final product, during the entire validity period when there was inoculation beyond the traditional yoghurt bacteria, bifidobacteria.

In the evaluation of the yoghurts, it was observed that there was significant influence of the time and the treatments in the value of the viable cell count, according to the graph in Figure 2.

Studies have shown that the yoghurt bacteria (S. thermophilus and $L$. bulgaricus) survive well in the product during shelf life. According to Tamine and Robinson (1991), the $\mathrm{pH}$ resulting from the bacterial metabolic activity could favor a certain group, to the detriment of the other. In the case of yoghurt, the bacteria of the Lactobacillus genus grow and tolerate lower $\mathrm{pH}$ values than those belonging to the genus Streptococcus. The degree of fall of the viable cell numbers during the storage is quite variable, ranging from a slight decrease to a fall of 4 logarithmic cycles at the end of product storage (Vinderola and Reinheimer, 2000).

\section{B. lactis culture count}

The survival of the probiotic bacteria in fermented milk products depends on several factors, such as the lineage used, interaction among the species present, culture conditions, chemical composition of the medium (carbohydrate source), final acidity, milk solids content, nutrient availability, growth promoters and inhibitors, sugar con- 


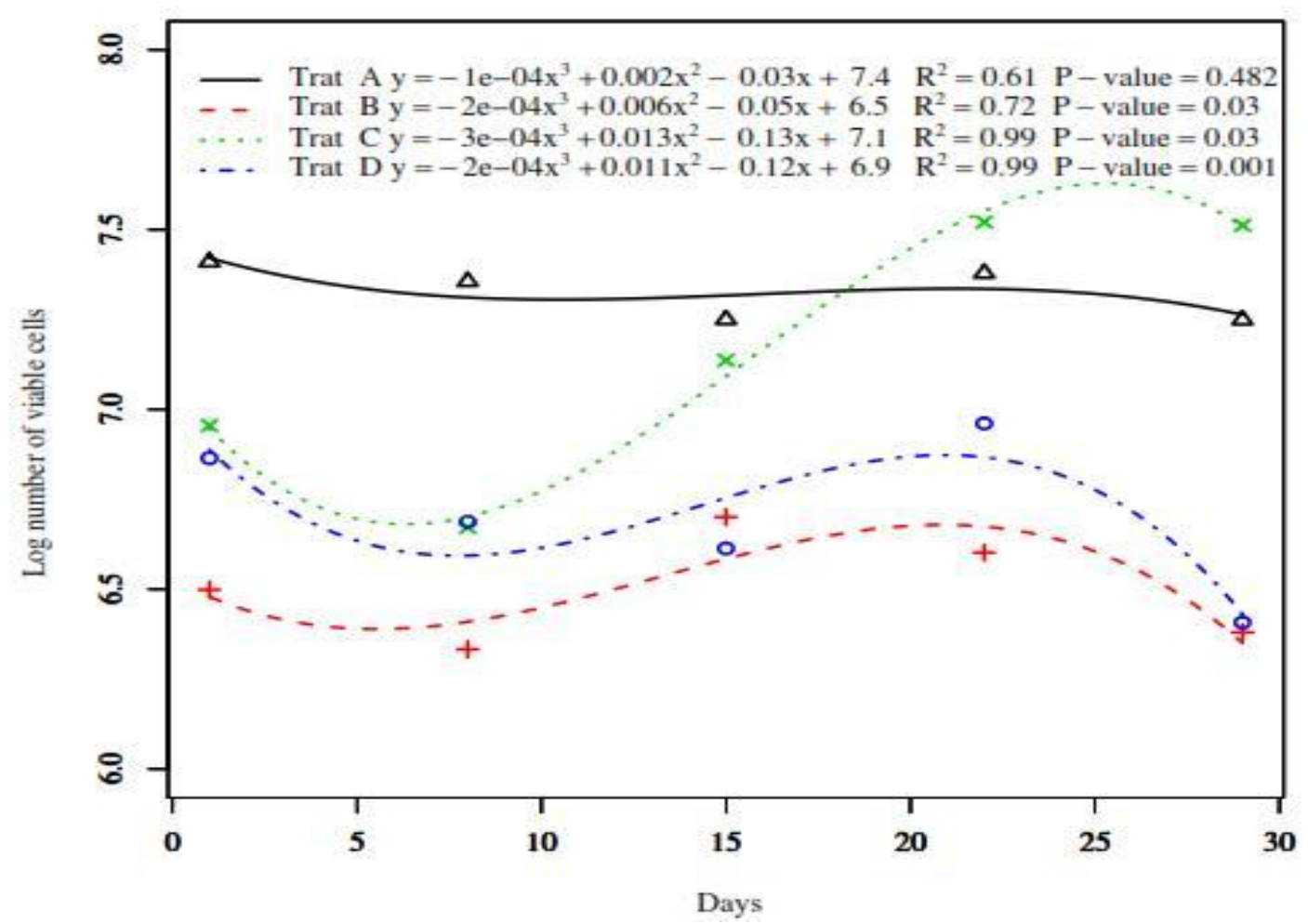

Figure 2. Regression model for the viable cell count (log CFU $/ \mathrm{mL}$ ) versus storage time at $4^{\circ} \mathrm{C}$, in yoghurts. Treatment: A (without addition of WSSE and without addition of probiotic culture), B (with addition of WSSE and without addition of probiotic culture), C (without addition of WSSE and with addition of probiotic culture), D (with addition of WSSE and with added probiotic culture).

Table 2. Average viable cell count of $B$. animalis ssp. lactis in goat milk yoghurt samples with added WSSE and probiotic culture during the storage time (CFU/ml).

\begin{tabular}{lccccc}
\hline \multirow{2}{*}{ Yoghurt } & CFU (ml) \\
\cline { 2 - 6 } & Day 1 & Day 8 & Day 15 & Day 22 & Day 29 \\
\hline C & $1.6 \times 10^{\circ}$ a & $6.5 \times 10^{\prime}$ a & $5.6 \times 10^{\prime}$ a & $6.7 \times 10^{\prime}$ a & $3.1 \times 10^{\prime}$ a \\
D & $1.1 \times 10^{\circ}$ a & $3.5 \times 10^{\prime}$ a & $3.1 \times 10^{\prime}$ a & $3.8 \times 10^{\prime}$ a & $2.7 \times 10^{\prime}$ a \\
\hline \multicolumn{7}{c}{ Means followed by same letter do not differ statistically among themselves, by } \\
Scott-Knott Test Average, to 5\% probability. Treatment: C (without addition of \\
WSSE and with addition of probiotic culture), D (with addition of WSSE and with \\
added probiotic culture).
\end{tabular}

centration (osmotic pressure), dissolved oxygen (especially for the Bifidobacterium ssp.), amount inoculated, incubation temperature and storage temperature duration (Lourens-Hattingh and Viljoen, 2001; Silva, 2007).

The average enumeration of viable $B$. animalis ssp. lactis cell colonies in the yoghurt treatments can be seen in Table 2. The average viable cell count of the B. lactis probiotic microorganism remained between $1.6 \times 10^{8}$ and $3.1 \times 10^{7} \mathrm{CFU} / \mathrm{mL}$ for the yoghurt $\mathrm{C}$, without WSSE addition, and the average count was $1.1 \times 10^{8}$ to $2.7 \times$ $10^{7}$ for the yoghurt $D$, with addition of water-soluble soy extract. From the ANOVA results, it can be observed that the average bifidobacteria count was not significantly influenced by the addition of soy extract. It is worth noting that the average viable cell count of the $B$. animalis ssp. lactis probiotic microorganism in the treatment without soy extract addition was slightly higher, however not significant, during the storage time of the yoghurts in comparison with the treatment with addition of this product. These results were contrary to the expected, because, according to Tamine et al. (1995), the soy contains prebiotics, such as rafinose and stachyose that are natural bifidobacteria growth promoters. It was 


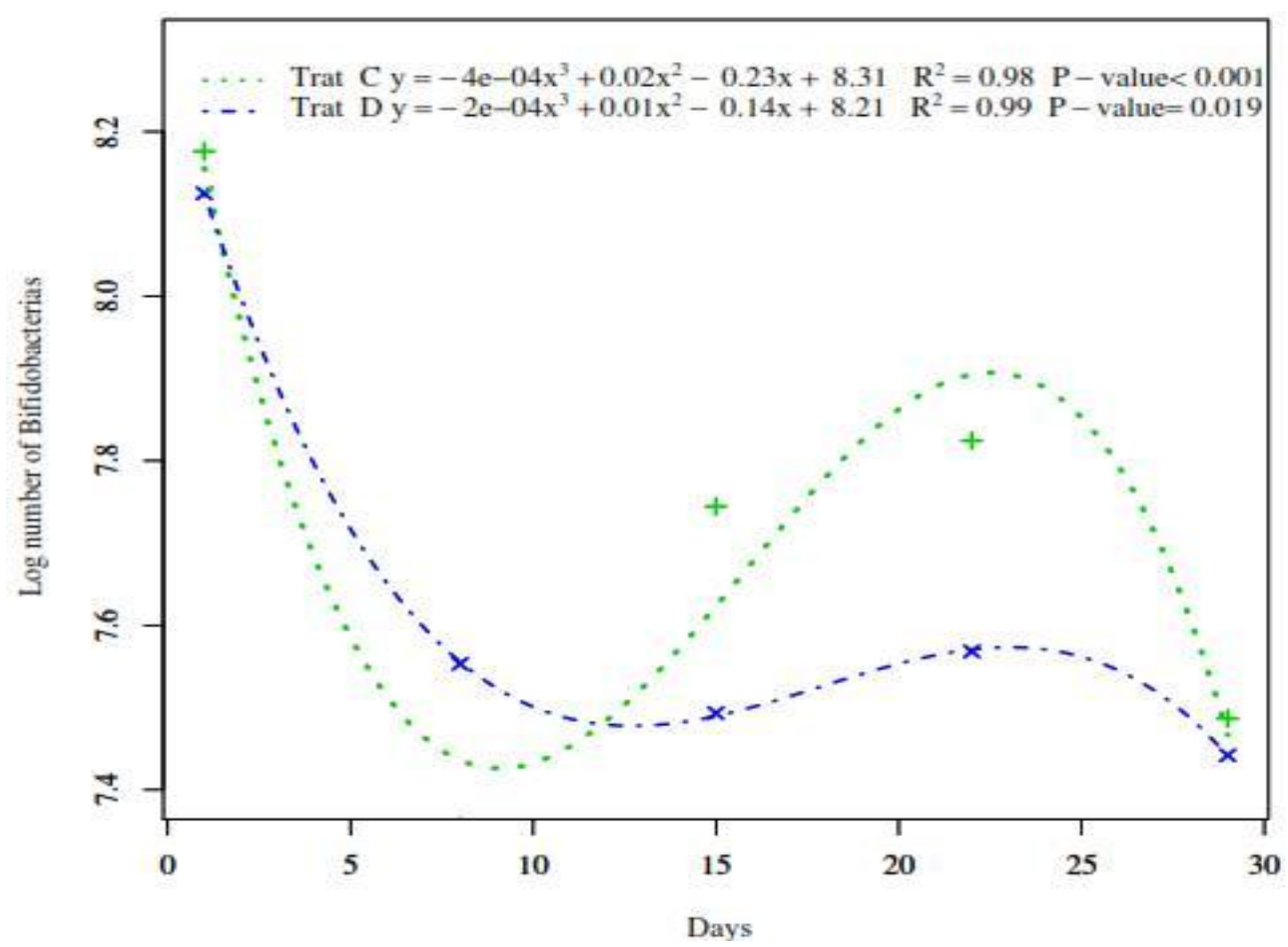

Figure 3. Regression model for bifidobacteria counts $(\log \mathrm{CFU} / \mathrm{mL})$ in function of storage time at $4^{\circ} \mathrm{C}$, in yoghurts. Treatment: C (without addition of WSSE and with addition of probiotic culture), D (with addition of WSSE and with added probiotic culture).

observed that the time influenced the bifidobacteria count in a significant way, according to the graph in Figure 3. The quality of a probiotic product is usually determined by the level, viability and amount of the probiotic cells in the food. This has been proposed as guarantee of the beneficial effects to human health (Schossler, 2009). Silva (2007) verified viability when evaluating species of Bifidobacterium and L. acidophilus probiotic bacteria in yoghurt development with the probiotic inulin.

According to Technical Regulation of Isolated Bioactive and Probiotic Substances with Allegation of Functional and/or Health Properties, Resolution RDC No.2, January 2002, probiotic is understood as live microorganisms capable of improving the intestinal microbial balance producing beneficial effects to the health of the individual (Brazil, 2002). Some benefits related to probiotic use are: stabilization of the intestinal function, reduction of infection by Helicobacter pylori, that is associated to gastritis and peptic ulcers and lactose intolerance symptoms relief. Other advantages in the use of these microorganisms are: the conservation of the milk through the production of lactic acid and possibly antimicrobial compounds; the production of flavor and aroma compounds and other metabolites that will provide a product with sensorial properties desirable to the consumer; the improvement of the nutritional value of the food, for instance, through the liberation of free amino acids or vitamin synthesis; the provision of therapeutic properties and special prophylaxis for cancer prevention and control of serum cholesterol levels. The potential benefits are resultant from the bacterial development and action during the fermented food production (Parvez et al., 2006).

\section{Conclusions}

This study showed that the viable cell count in the yoghurts was satisfactory without addition of watersoluble soy extract and also for those with added $B$. animalis ssp. lactis probiotic culture during the period appraised, therefore, the yoghurts were considered in accordance with the current law. However, the treatment with only added water-soluble soy extract was not shown viable according to the legislation; therefore it cannot be considered a yoghurt in that respect. The addition of the $B$. animalis ssp. lactis probiotic culture in the yoghurts with goat milk was shown viable during the storage time.

\section{REFERENCES}

Alférez MJM, López-Aliaga I, Nestares T, Díaz-Castro J, Barrionuevo M, Ros PB, Campos MS (2006). Dietary goat milk improves iron bioavailatability in rats with induced ferropenic anaemia in comparison with cow milk. Int. Dairy J. 16:813-821.

Allgeyer LC, Miller MJ, Lee SY (2010). Sensory and microbiological 
quality of yogurt drinks with prebiotics and probiotics. J. Dairy Sci. 93:4471-4479.

Brazil (2000a). Ministry of Agriculture, Livestock and Supply. Normative Instruction n. 37 of 08 November 2000. Technical Regulation identity and quality of goat milk. Official Gazette, Brasilia, 09 November.

Brazil (2000b). Ministry of Agriculture, Livestock and Supply. Standards of identity and quality of fermented milks. Official Gazette [of] the Federative Republic of Brazil. Brasilia, Resolution no. 5, DE13 November 2000b. 9 p. November 27. Section I.

Brazil (2002). National Agency for Sanitary Vigilance. RDC Resolution No. 2 of January 7, 2002. Creates the Technical Regulation of Bioactive Substances and Probiotics Isolates with Alleged Functional Properties and Health Official Gazette [of] the Federative Republic of Brazil, Brasilia, DF, 7, January.

Brazil (2006). Ministry of Agriculture, Livestock and Supply. Official analytical methods for physico-chemical control of milk and dairy products. Normative Instruction. 68 of December 12.

FAO/WHO (2001). Health and nutritional properties of probiotics in food including powder milk live lactic acid bacteria. Report of a Joint FAO/WHO Expert Consultation on Evaluation of Health and Nutritional Properties of Probiotic in Food Including Powder Milk with Live Lactic Acid Bacteria. WHO, Geneva, Switzerland.

Hugenholtz $J$ (2008). The lactic bacterium as a cell factory for food ingredient production. Int. Dairy J. 18:466-475.

Instituto Adolfo Lutz (1985). Analytical standards of the Instituto Adolfo Lutz. 3.ed. São Paulo: IMESP, v. 1, 533p.

Isleten M, Karagul-Yuceer Y (2006). Effects of dried dairy ingredients on physical and sensory properties of nonfat yogurt. J. Dairy Sci. 89:2865-2872.

Kozloski GV (2002). Biochemistry of ruminants. Santa Maria: UFSM, $140 \mathrm{p}$.

Lora SCP, Prudêncio ES, Benedet HD (2006). Sensory evaluation of ice cream made with goat milk. Semina Ciênc. agrar. 27:221-230.

Lourens-Hattingh A, Viljoen BC (2001). Yogurt as probiotic carrier food. Int. Dairy J. 11: 1-17.

Martín-Diana AB, Janer C, Peláez C, Requena T (2003). Development of a fermented goat's milk containing probiotic bacteria. Int. Dairy J. 13:827-833.

Parvez, KA, Malik KA, Kang SA, Kim HY (2006). Probiotics and their fermented food products are beneficial for health. J. Appl. Microbiol. 100:1171-1185.
R Developmente Core Team (2009). R: a language and environment for statistical computing. Vienna: R Foundation for Statistical Computing.

Ribeiro AC, Ribeiro AC (2010). Specialty products made from goat milk. Small Rumin. Res. 89:225-233.

Schossler LS (2009). Feasibility study of probiotic microorganism (Bifidobacterium lactis) applied to cooked meat product. Dissertation (MSc in Food Science and Technology) - Federal University of Santa Maria, Santa Maria. p. 76.

Silanikove N, Leitner G, Merin U, Prosser CG (2010). Recent advances in exploiting goat's milk: Quality, safety and production aspects. Small Rumin Res. 89:110-124.

Silva DCG, Abreu LR, Assumpção, GP (2012). Addition of watersoluble soy extract and probiotic culture, viscosity, water retention capacity and syneresis characteristics of goat milk yogurt. Cienc. Rural 42:545-550.

Silva SV (2007). Development of probiotic yoghurt with prebiotic. Dissertation (MSc in Food Science and Technology) - Federal University of Santa Maria, Santa Maria, 2007. p. 106.

Tabasco R, Paarup T, Janer C, Pelaez C, Requena T (2007). Selective enumeration and identification of mixed cultures of Streptococcus thermophilus, Lactobacillus delbrueckii subsp. bulgaricus, L. acidophillus, L. paracasei and Bifidobacterium lactis in fermented milk. Int. Dairy J. 17:1107-1114.

Tamine AY, Marshall VMR, Robinson RK (1995). Microbiological and technological aspects of Milk fermented by Bifidobactéria. J. Dairy Res. 62:151-187.

Tamine AY, Robinson RK (1991). Yogurt: ciencia y tecnología. Zaragoza: Acribia, p. 368.

Tebaldi VMR, Resende JGOS, Ramalho GCA, Oliveira TLC, Abreu LRA, Piccoli RH (2007). Avaliação microbiológica de bebidas lácteas fermentadas adquiridas no comércio varejista do sul de Minas Gerais. Ciênc. Agrotec. 31:1085-1088.

Vinderola CG, Reinheimer JA (2000). Enumeration of Lactobacillus casei in the presence of $\mathrm{L}$. acidophilus, bifidobacteria and lactic starter bactéria in fermented dairy products. Int. Dairy J. 10:271-275. 